\title{
Teachers and Students Appraisal Of Secondary School As Custodian Of Moral Values
}

\author{
Bello Bolanle Muhinat \\ Senior Lecturer Department Of Social Sciences Education, Faculty Of Education, Universitas Of Ilorin \\ Email : bello.mb@unilorin.edu.ng
}

\begin{abstract}
This study examines how secondary school plays its role as a custodian of moral values in society. What it takes to teach moral values in the school. What are the facilities, subjects, punishments, as well as teaching methods adopted by the school? All these are what the study set out to examine. This was verified using 15 purposively sampled secondary schools in the Sokoto metropolis. The study adopted a descriptive survey design. A questionnaire with psychometrics properties of 0.72 and 0.81 for validity and reliability respectively, was used to elicit the needed data from the respondents which constituted both teachers and students of the selected schools. The findings reveal the current state secondary school Sokoto state lacks in its role to serve as a custodian of moral values, from its facilities, subjects, enforcing conformity, and teaching strategies. In conclusion, for secondary school to perform its role as custodian of moral values, it was recommended among others that there should be the provision of more facilities conducive to teaching and learning in the schools to enable the secondary school plays its role as a custodian of moral values in the society.
\end{abstract}

Keywords : Custodian; Moral; Conformity; Example; and Explanation

\begin{abstract}
Abstrak. Studi ini mengkaji bagaimana sekolah menengah memainkan perannya sebagai penjaga nilai-nilai moral dalam masyarakat. Apa yang diperlukan untuk mengajarkan nilai-nilai moral di sekolah. Apa fasilitas, mata pelajaran, hukuman, serta metode pengajaran yang diadopsi oleh sekolah? Semua ini adalah apa yang ingin diteliti oleh penelitian ini. Ini diverifikasi menggunakan 15 sekolah menengah sampel purposive di kota metropolitan Sokoto. Penelitian ini mengadopsi desain survei deskriptif. Kuesioner dengan sifat psikometrik masing-masing 0,72 dan 0,81 untuk validitas dan reliabilitas, digunakan untuk memperoleh data yang dibutuhkan dari responden yang merupakan guru dan siswa dari sekolah yang dipilih. Temuan menunjukkan sekolah menengah negeri Sokoto saat ini kurang berperan sebagai penjaga nilai-nilai moral, mulai dari fasilitas, mata pelajaran, penegakan kesesuaian, dan strategi pengajaran. Kesimpulannya, agar sekolah menengah dapat menjalankan perannya sebagai pemelihara nilai-nilai moral, antara lain direkomendasikan untuk menyediakan fasilitas yang lebih kondusif untuk belajar-mengajar di sekolah agar sekolah menengah dapat berperan sebagai pemelihara. nilai moral yang ada di masyarakat.
\end{abstract}

Keywords : Pemelihara; Moral; Kesesuaian; Contoh; dan Penjelasan

\section{PRELIMINARY}

The traditional role of the family in the olden days' society has changed and has been replacing with modern functions. This is because family structure has also changed, which is from an extended or compound family to the nuclear family. This type of family is where parents or families live separately from one another and child-rearing and training become solely the responsibility of this isolated nuclear family. That was the beginning of laxity in the behaviour and upbringing of these children, this is because every member of the extended or compound family has a role to play in the socialization process of the child. Modern-day, parents are out of their homes either struggling to make ends meet or trying to keep their profession. Mothers wake up very early in the morning go to 
work and will not return until very late at night, been a banker, Doctor, or manager of a company, while fathers also run its own. These parents have little or no time at all for their children and in most cases, they are kept in the care of a house help or at times put them in boarding school as early as their primary school age, most recently they do not enroll their children in school that does not have a school bus, they expected the school to come home and pick these children up and also bring them back from school. They now saddled the school with the greater responsibility of training these children. They expect both moral and academic training. Forgetting the fact that school can only compliment the moral foundation existing in the children put in their care which the family has laid. It is the family especially the mother that plays a key role in the character and moral training of the children before they get to the larger society.

Failure on the part of the parents in the performance of their roles and responsibilities to their children, moral decadence in the society is the order of the day. The family expects the school to train and reshape these children for them. The school in question has its problem, which ranges from the influence of other social forces in society. According to Ballantinev, (2015) the school is not an island on its own. It is considered the miniature of the society, which means that what so ever happens in society find its ways into the school system.

Schooling in Nigeria is now for general and not on any particular ground, but the fact is that society needs it for survival. The functions of school according to structural-functional analysis are to direct attention to how education maintains social integration, contribute to socialization, appropriate social placement, and encourage cultural innovation (Ballantinev, 2015). This means that the primarily any formal institution like schools should be to socialize individuals into the common culture and enable them to function successfully within it.

Education in Nigeria at both secondary and tertiary institutions has changed from what it used to be, this is because school administrators seem to be losing grip of their institutions to various groups, some of them fearless, some armed with dangerous weapons, some with other diabolic powers and resources. They threaten, bully, attack, maim, and even kill colleagues as well as teachers without hindrance. They implant fear in the minds of other students and the school community, Oftentimes, they are not traceable by the forces or even the school authority, and where they are traced and arrested, they soon gain their freedom. Apeabu (2014) tries to draw a comparison between schooling in the pre-sixty days with post-sixty days and come up to maintain that the two are incomparable because this is because the Nigerian society of post-sixty has become individualistic and non-caring. The youth today do not know what it means to be one's brother's keeper. The student demonstrates this when it comes to holding up responsibility; they tend to satisfy personal interest first before considering others.

The issue of moral shift, shifting the goal post, there is a significant shift from moral and morality in society. stakeholders in the education industry no longer believe that Nigerian society has any moral norms; because human lives, property, and other things, which used to be, regarded as sacred in the early era no longer matters today. Honesty no longer matters, the language of the adults is no longer understood by the youths. Very few youths today understand the non-verbal communication of their parents, while the adults are always uncertain about which to behave, talk, dress. Such disorder is not necessarily the fault of the schools. Schools reflected the larger society of which they are part of and when a community is characterized by violence, its schools are likely to confront disciplinary problems. In the view of Macionis, (1989) he suggests that schools as an agent of socialization do have the power to effect changes for the better.

And it is based on this that Durkheim in Ottaway (2010) sees school as in a better position to inculcate moral values in students through the rules and regulation set out by the school which the students need to respect, that, it is by respecting these rules that the child learns to respect rules in general, that will help in the development of ethically mature adults with positive societal attitudes. Moral education is what the schools teach to help the young to become ethically mature adults, capable of moral thought and action. Very little of the moral education that inevitably occurs in the schools are formally recorded in lesson plans, curriculum guides, or behavioural objectives 
(Durkheim in Hurn, 1993). Many aspects of moral education are part of the hidden curriculum. Although there are no "Moral Aptitude Test" scores to verify this fact, students do learn. They develop conceptions of what being a good person entails. They learn what their obligations are (if any) to the group and the larger society. They acquire a sense of their rights as individuals. In other words, moral education has a certain inevitability. There is a popular saying that no individual can effectively teach morale to students in the four walls of the classroom by mere lecturing model rather students caught morale through various activities. In the work of Ryan (1986) pointed out strategies that could be adopted effective teaching of moral to school.

\section{Literature Review}

Ryan highlighted it as "THE FIVE Es" through which morals should be taught in school, these are Example, Explanation, Exhortation, Environment, and Experience.

Example. The most obvious form of moral education in the classroom is the example teachers provide for their students. This troubles many teachers. Those who came through the era of teacheras-technician are put off by the notion that teachers are supposed to be models of moral excellence for their students. Nonetheless, research has now confirmed what humankind long ago recognized intuitively: people with power and prestige are imitated by those around them. And, though some teachers may not think of themselves as figures of power and prestige, the students they teach certainly see them as such. Students watch their teachers find out how grown-ups act. Therefore, teachers need to be constantly aware of the powerful influence that their actions in the classroom have on students. Kotaiah (2014) in his research stated that home is the first place while schools and teachers are the second places to influence the morality of the children. He stated that teachers play a vital role in fostering the moral qualities of the students regardless of what subjects they teach. The teacher's conduct helps shape students' moral behavior. Therefore, teachers should set a standard of moral behavior before the students. Teachers can foster various moral qualities in the students through both curricular and co-curricular activities. He also suggested a list of activities for the moral development of children in his paper which could give more ideas for the teachers. The activities include class discussion, group projects, role play, a celebration of festival, camp, etc.

Explanation: It takes years of poor teaching to subdue a child's natural curiosity. Much of children's inquisitiveness is directed at moral issues: "Why am I being punished, and he isn't?" "How could a great man like Mandela be imprisoned for several years? And why was Sharia legal system introduce in the northern part of Nigeria?". What do I owe my neighbour?" "Is it fair?" "Is it right?" "What should I do?" what is excepted of a teacher is to explain the moral order to these young. Durkheim (1968) in Ryan (1986), strongly endorsed the school's active efforts to instill in the young its values and rules of conduct. However, Durkheim maintains that "To teach morality, is neither to preach nor indoctrinate; it is to explain". We need to teach moral education through explanation not simply to stuff students' heads with the rules and regulations of society, but to engage them in the great moral conversation of the human race.

Exhortation: is defined as the act or process of making a strong urging or appeal. An example of an exhortation is an emotional speech that inspires learners to act. Explanations could are also a very crucial part of children's moral education, but teachers' urgings or appeal, emotional speech work very well in the process of teaching and learning of morals.

Environment: this is usually established for teaching and learning. This purpose may however not be achieved when the constituting components of school environments like school buildings, library facilities, furniture items, instructional materials, as well as resources that could be either human or materials among others are either not available, inadequate, or not properly structured and 
organized for the promotion of effective teaching and learning. A classroom is a small society with patterns and rituals, power relationships, and standards for students' behaviour and academic performance. In an effective classroom, students are respected and respect one another, the standards of excellence are reachable, and students' satisfaction comes from achieving those standards. A moral classroom environment is greatly affected by conditions and factors outside the classroom, such as a hostile school environment or a pleasure-oriented community.

The notion of trust and honesty combined with the ethics of care and compassion would help a long way with this aspect. Students are unlikely to relate to or discuss issues with moral education teachers who are authoritarian or who focus only on examination and syllabus content. In the finding of Fayose (2014) it was revealed that availability coupled with effective utilization will go along way in the effective teaching and learning of moral values in schools. The study further categorised these school facilities or resources into two which are hardware and software. Hardware includes buildings, the library, furniture, textbooks, the laboratory, school equipment. While the software includes: the visual teaching aids and instructional materials among others. The school environment and the teacher as a moral person, for instance, are extremely significant in the training of students' moral development (Power, Higgins, \&Kohlberg, 1989). In the studies of Sanderse, (2012), and Hansen (2001), besides school environment and teachers as moral Exemplars, studentsteacher interaction also constitute significantly to effective teaching of moral values of the society in school to build in them a moral citizen.

Experience : Aristotle said that a man becomes virtuous by performing virtuous acts; he becomes kind by doing kind acts; he becomes brave by doing brave acts. A school that institutes a community service programme is merely operationalising Aristotle. And a teacher who takes on the new moral education is simply reassuming a responsibility traditionally assigned to teachers. The role of the school is not simply to make learners smart but to make them smart and good.

The school has to struggle to be meet up with this responsibility of training learners to be morally, and academically upright to be able to contribute to the development of society. How then can the school help in the training of the students into becoming a mature adult with sound moral values? This was part of the researchable gap to be filled by the study. The following questions were answered: Does the school have enough resources in terms of both human and material for teachings of moral values?

a. What is the subject set aside by the school that helps in the teaching of sound moral values?

b. What are the types of punishment adopted by the school to enforce school rules and regulations?

c. What are the school activities set aside by the school that help in the teaching of sound moral values?

d. What are the methods schools adopt in the teaching of moral values?

\section{RESEARCH METHODS}

Upper basic and senior school teachers and students in the Sokoto metropolis constituted the population while those from public schools are the target population. There are a total of 26 secondary schools out of which 15 were purposively sampled in the study. the stratified sampling procedure was adopted in the selection of upper basic 3 and Senior school students 2 for the study. Making a total population of 3,218 and 1,210 students and teachers respectively out of which a sample size of 678 was selected. This is in line with the research advisors' (2006) table for sample size selection, which stated that the best sample size for a population of 3,500 to 5,000 at a 0.05 significant level and a margin of error of $3.5 \%$ is 678 (486 and 192 students and teachers respectively).

The descriptive survey design was adopted in the study, the choice of the descriptive design was in line with Sambo (2008), who maintained that it is concerned with the gathering of 
information on peoples' opinion. Meaning that the choice of this design was considered most appropriate because the study sampled teachers' and student's appraisal of secondary school as a custodian of moral value. A researchers' designed questionnaire entitled "An appraisal of secondary school as custodian of moral values" was used to elicit the needed data for this study. Its psychometric properties were .072 content validity and 0.81 reliability index was obtained using Person's Product Moment correlation a test-retest method. A self-administration approach to the collection of data was used. The data collected was analyzed using simple frequency percentage, mean score, and standard deviation.

\section{RESULTS AND DISCUSSION}

\section{a. Results}

Both the students and the teacher's responses were collated and sum into a lump sum for easy analysis.

Research Question One: Does the school have enough resources in terms of both human and material for teachings of moral values

Table 1. Responses on facilities available for teaching moral values

\begin{tabular}{lllll}
\hline S/No & Statements & N & Mean & Std.D \\
\hline $\mathbf{1}$ & $\begin{array}{l}\text { Human Resources } \\
\text { Numbers of experts teaching } \\
\text { the various school subjects }\end{array}$ & 678 & 1.00 & 0.02 \\
& & & \\
& $\begin{array}{l}\text { Teachers- students ratio } \\
\mathbf{2}\end{array}$ & 678 & 1.52 & 0.49 \\
& Educational Resources & & & \\
& School Library & 678 & 1.10 & 0.21 \\
& Audio aids & 678 & 1.56 & 0.49 \\
& Visual Aids & 678 & 1.70 & 0.99 \\
& Audio- visual & 678 & 1.61 & 0.48 \\
& Dimensional aids & 678 & 1.42 & 0.74 \\
& & & & \\
$\mathbf{3} \quad$ Material Resources & & & \\
& Chalkboard & 678 & 1.05 & 0.31 \\
& Bulletin board & 678 & 1.44 & 0.76 \\
& Textbooks & 678 & 1.41 & 0.49 \\
& Models & 678 & 1.39 & 0.62 \\
& Journals & 678 & 1.62 & 0.51 \\
& Newspapers & 678 & 1.30 & 0.66 \\
\hline
\end{tabular}

(Fieldwork: 2019)

$$
\text { Weighted average } \mathbf{- 2 . 0}
$$

Table 1 revealed the mean scores of responses ranging from 1.00 to $1.70<2.0$ weighted mean. This is an indication that the resources available in secondary schools are not available for the effective teaching of moral values.

Research Question two : What are the subject and activities set aside by the school that helps in the teaching of sound moral values? 
Table 2 : Percentages Of The Moral Subject Taught In School and Made Compulsory

\begin{tabular}{llll}
\hline S/N & School subject & $\begin{array}{l}\text { Compulsory and all } \\
\text { levels (\%) }\end{array}$ & $\begin{array}{l}\text { Not compulsory at } \\
\text { all levels }\end{array}$ \\
\hline 1. & Civic Education & 100 & ---- \\
2. & Social Studies & --- & 100 \\
3. & $\begin{array}{l}\text { Religion Studies (I.R.K } \\
\text { and C.R.K) }\end{array}$ & & 100 \\
4.-- & $\begin{array}{l}\text { Other National Value } \\
\text { Subjects (Security }\end{array}$ & \\
& $\begin{array}{l}\text { education) } \\
\text { 5. }\end{array}$ & History & 100 \\
6. & Literature in English & ---- & \\
7. & Government & ---- & 100 \\
\hline
\end{tabular}

(Fieldwork: 2019)

Table 2 revealed only one out of seven moral subjects taught in secondary school has been taught to students at all levels of the school that is for all students. Six of the seven subjects are compulsory at the upper basic level while only one is for both upper basic and senior school. Research Question Three: What are the types of punishment measures adopted by the school to enforce school rules and regulations?

Table 3 : Frequency and Percentage Of The Responses

\begin{tabular}{|c|c|c|c|c|c|}
\hline & Offenses & $\mathbf{N}$ & $\begin{array}{l}\text { Corporal } \\
\text { Punishment }\end{array}$ & Suspension & $\begin{array}{l}\text { Others (counselling, } \\
\text { caution, report to } \\
\text { principal, expulsion, } \\
\text { Picking papers, etc.) }\end{array}$ \\
\hline 1 & $\begin{array}{l}\text { Lateness to } \\
\text { school }\end{array}$ & 678 & $518(76 \%)$ & 0 & $160(24 \%)$ \\
\hline 2 & Truancy & 678 & 604 (89\%) & $17(3 \%)$ & $54(8 \%)$ \\
\hline 3 & Stealing & 678 & 611 (90\%) & $12(2 \%)$ & $55(8 \%)$ \\
\hline 4 & $\begin{array}{l}\text { Rudeness to } \\
\text { teachers }\end{array}$ & 678 & 591 (87\%) & 0 & 87 (13\%) \\
\hline 5 & $\begin{array}{l}\text { Assault and } \\
\text { Insult on } \\
\text { teachers and } \\
\text { non-teachers }\end{array}$ & 678 & 629 (93\%) & 0 & $49(7 \%)$ \\
\hline 6 & $\begin{array}{l}\text { Assault on } \\
\text { school prefects }\end{array}$ & 678 & 438 (65\%) & 0 & $240(35 \%)$ \\
\hline 7 & $\begin{array}{l}\text { Violating dress } \\
\text { code }\end{array}$ & 678 & 391 (58\%) & 0 & 287 (42\%) \\
\hline 8 & Vandalism & 678 & 311 (46\%) & 291 (43\%) & 76 (11\%) \\
\hline 9 & Cultism & 678 & $51(7 \%)$ & 517 (76\%) & $110(17 \%)$ \\
\hline 10 & $\begin{array}{l}\text { Drug abuse } \\
\text { and alcoholism }\end{array}$ & 678 & $43(6 \%)$ & 492 (72\%) & $143(22 \%)$ \\
\hline 11 & Sexual Issues & 678 & 163 (24\%) & 319 (47\%) & 196 (29\%) \\
\hline
\end{tabular}

(Fieldwork: 2019) 
Table 3 revealed that Corporal punishment is mostly used as corrective measures in most schools, while the suspension and other punishments like a warning, caution, counselling, etc are least used. By implication, the most commonly adopted type of punishment created more moral problems for the learners than correcting them.

Research question 4 : What are the activities set aside by the school that helps in the teaching of sound moral values?

Table 4 : Percentages Of Activities In The School

\begin{tabular}{|c|c|c|c|c|c|}
\hline $\mathrm{S} / \mathrm{N}$ & Activities & Available & Not Available & Functional & $\begin{array}{l}\text { Not } \\
\text { Functional }\end{array}$ \\
\hline 1 & $\begin{array}{l}\text { School } \\
\text { song/anthem }\end{array}$ & -- & 100 & -- & -- \\
\hline 2 & $\begin{array}{l}\text { Guidance \& } \\
\text { Counselling Unit } \\
\text { of the school } \\
\text { with different } \\
\text { counselling } \\
\text { programmes }\end{array}$ & $571(84 \%)$ & $107(15 \%)$ & $121(18 \%)$ & -- \\
\hline 3 & $\begin{array}{l}\text { Co-curricular } \\
\text { (Clubs and } \\
\text { societies) }\end{array}$ & & & & \\
\hline a. & Art club & $92(14 \%)$ & $586(86 \%)$ & $71(11 \%)$ & --- \\
\hline b. & $\begin{array}{l}\text { Junior Engineers, } \\
\text { Technician and } \\
\text { Scientists club } \\
\text { (JETs) }\end{array}$ & $43(6 \%)$ & $635(94 \%)$ & $40(6 \%)$ & --- \\
\hline c. & Drama club & $6(1 \%)$ & 677 (99\%) & $3(1 \%)$ & --- \\
\hline d. & Debate club & $294(43 \%)$ & $384(57 \%)$ & $76(11 \%)$ & --- \\
\hline e. & $\begin{array}{l}\text { Mathematics } \\
\text { club }\end{array}$ & $5(1 \%)$ & 675 (99\%) & $0(0 \%)$ & --- \\
\hline f. & Mentorship & $0(0 \%)$ & $678(100 \%)$ & $0(0 \%)$ & --- \\
\hline g. & Red Cross Society & $111(16 \%)$ & 567 (84\%) & $45(6 \%)$ & --- \\
\hline h. & Girl Guide & $4(1 \%)$ & $674(99 \%)$ & $0(0 \%)$ & --- \\
\hline i. & Man-O- War & $67(9 \%)$ & $615(91 \%)$ & $37(5 \%)$ & --- \\
\hline j. & Boys scout & $15(2 \%)$ & $663(98 \%)$ & $0(0 \%)$ & --- \\
\hline k. & $\begin{array}{l}\text { School } \\
\text { newspaper club }\end{array}$ & $26(4 \%)$ & 652 (96\%) & $0(0 \%)$ & --- \\
\hline I. & Dance club & $0(0 \%)$ & $678(100 \%)$ & --- & --- \\
\hline m. & Games club & $351(52 \%)$ & $327(48 \%)$ & $219(32 \%)$ & --- \\
\hline n. & $\begin{array}{l}\text { Muslim Students } \\
\text { Society of Nigeria } \\
\text { (MSSN) }\end{array}$ & $678(100 \%)$ & 0 & $481(71 \%)$ & --- \\
\hline o. & $\begin{array}{l}\text { Christian } \\
\text { Students } \\
\text { Fellowship }\end{array}$ & 687 (100\%) & $0(0 \%)$ & 501 (74\%) & --- \\
\hline
\end{tabular}

Source : (Fieldwork 2019) 
Table 4 shows that, the guidance \& counseling units of the school with different counselling programmes of the students, such as bullying and behavioural modification therapy available but not functioning, no school anthem of the song. And lastly out of the 15 Co-curricular activities present in the sampled schools were mostly not available or functioning less than $50 \%$. Except for the Muslim Student Society of Nigeria and Christian Students Fellowship.

Research Question Five : What are the methods schools adopt in the teaching of moral values?

Table 5: mean score of teaching methods adopted

\begin{tabular}{lllll}
\hline & Teaching method & $\mathbf{N}$ & Mean & Std.D. \\
\hline 1. & Example & 678 & 1.40 & 1.00 \\
2. & Explanation & 678 & 1.49 & 1.04 \\
3. & Exhortation & 678 & 1.64 & 0.18 \\
4. & Environment of the & 678 & 1.33 & 1.71 \\
& school & & & \\
5. & Experience & 678 & 1.31 & 1.60 \\
\hline
\end{tabular}

Fieldwork 2019)

Weighted Average: 1.80

Table 5 revealed a mean score range of 1.31 to $1.64<1.80$ weighted mean. By implication, secondary school teachers failed in the use of Five Es for the teaching of moral values to students. Respondents all attested to the fact that the school environment of today does not encourage the teaching of sound moral values.

\section{b. Discussion}

Too many students in our classroom compare to the numbers of teachers available to handle them, only $27 \%$ of the sample schools have a population of $70-80$ teachers in their school, while $73 \%$ are less than that. This large class hinders teachers' effectiveness in the area of teaching and also noticing when students absent themselves from the class or school in general. In all the schools sampled, there is no situation of the ratio of one teacher to forty students (1:40) which is in line with the Teacher- students ration set in the National Policy on Education, the situation on the ground violated this set standard.

Students' leisure time or free periods so to say are wastefully spent because there is no library in most of the sample schools only a few attested to the fact that their school has a building they referred to as library where relevant moral books are absent. This issue of students learning by themselves through reading does not exist in such schools, except for what the teacher gives or teach in the classroom. Morel training and good character development go beyond that the traditional classroom teaching and the learning situation, students need to develop on their own, discover reasons they need to help other members of their community, why they need to respect people in authority, why they need to be great and be a useful member of the society which they belong from literature books writing by grate authors like, Wole Soyinka, Chinua Achebe, Ola Rotimi among others. All the respondents attained to the fact that even where these facilities are available in their school were either in poor condition or too obsolete for students' utilization.

Secondary Schools today (upper basic and senior schools) do not have any special subject through which sound moral values can be taught to students. As evident from the finding of the study. some of the subjects investigated, findings revealed that some of the subjects such as Religions studies, social studies, security education which school pretends to be using were only made compulsory at the upper basic class but optional at the senior class. 
When teachers have to correct students when they misbehave or failed to conform to school rules and regulations, all the respondents attested to the fact that they resulted in constant use of a cane (or any other form of Corporal punishment) as it was evident from the finding of the study. This is because teacher sees it as the best way of enforcing conformity to school rules and regulation, but forgotten the fact that they would have created better conformity to rules if explanation, seeing teachers as a role model or taking them through counseling process is adopted and also to find out why the misbehaved student behave the way they behaved. This finding is in agreement with Adeshina (1990) argues that if proper punishment is used for a particular offense it will create conformity, but if otherwise, it will create deviant. That is why the type of punishment to be given should be the one that will deter other students from committing similar or the same offence behave the same way, and not the one that will harden them the more. While the finding Chianu (2001) disagrees with this finding by maintaining that students would master habits better and utilized effectively if teachers gave them doses of corporal punishment. Contrary to this finding, were the findings of many researchers such as Rigby (2011) whose study revealed that corporal punishment has shock and dehumanizing value and made the school learning environment a punitive place.

According to him, fear of physical punishment inhibited creativity in students, damaged teacher-student relationships, and could not effectively change repeated misbehavior. Activities which should have been present in the school to enhance smooth teaching of moral values and developing good character in students are practically absents in most of the sampled schools, most especially clubs and societies. Only $1 \%$ and $6 \%$ of the respondents have non-functioning drama and JET clubs respectively. The school failed to release that a hidden curriculum exists in the school as a result of other activities that are going on in the school. The better character can be developed in students through drama. Drama makes the student learners with easy and keeps them better informed about what is happening in society. For instance, The role Television programmes and films played in the enlightenment campaign cannot be overemphasis e.g COVID-19 pandemic awareness campaign create serious awareness in the mind of every Nigerians. Meaning that drama would have been the best instrument through which good character and moral values can be developed in students. This finding corroborated those of Colby (1987); Winston, (2010); Edmiston (1995), and Winston (1998) whose findings revealed that Drama existence of drama club in school and students participation in drama helps to build good moral and ethical potential that is needed in the society as well built-in them the power of better understanding of societal issues and possible solution. Students' engagement in a religious society like the Muslim and Christian society is meant to perform two main functions, that is welcoming orientation for the new officers and send forth a programme of the graduating members especially the executives. Debating club available but not functional while hosting others not available.

Despite the effectiveness and the value of Ryan FIVE Es teaching strategies in the teaching of moral values to students that as Explanations, Examples, good school Environment, Experience, and Exhortation, it was not adopted in the teaching of moral values in sampled schools. This was evident from the finding of the study when all the respondents attended to the fact that the teaching of moral values became difficult because proper teaching strategy was not used. This finding agrees with those of Oser (1996), and Hansen (2001) which revealed that besides the school environment, teachers as moral Example, students- teacher interaction also constitute significantly to effective teaching of moral values of the society in school to build in them a moral citizen.

\section{CONCLUSION}

In conclusion, for secondary school to perform its role as custodian of moral values, It must possess two vital features which are; compulsion and coercion, like in prisons and mental homes. Thus, schools are places where order and authority are problematic. If students have more positive incentives to conform to school rules than prisoners, only a few corrupt individuals can influence 
others or the majority. To control these individuals, schools have rather fewer resources at their disposal. In light of the above findings, the following recommendations are put forward as a way of maintaining or improving the role of the school as a custodian of moral values:

a. There should be the provision of more facilities (classrooms and libraries with good storybooks) conducive to teaching and learning in the present schools.

b. Religious teaching should continue in secondary schools throughout the levels, and not stop at the upper basic school. There is a need for the introduction of Moral instruction in the school curriculum at the secondary school. Every school needs to make sure that its students take part in co-curricular activities and be made compulsory in schools because it helps in the adjustment and development of physical, emotional, mental, and social aspects of adolescents. Counselling centers should also be established in schools so that students can consult the counsellor and obtain necessary personal guidance, and students with bad behaviour can be counselled and advised as well as monitored.

c. Suitable punishment should be adequately used to create conformity in the students. Different offences should attract different and special ways of correcting or punishing the student.

d. Teachers should always explain to students what and why they need to be of good character and what it takes to be of good character. And also create a favourable school environment and be of a good example for students to emulate.

\section{BIBLIOGRAPHY}

Aboderin, Y. (2011). Teacher education today. Journal on committee of provost of College of education Nigeria. 1 (4), 65-70.

Adesina, S. (1990). Education management. Fourth Dimension. Enugu: Harper Publishers.

Akinkugbe, O.O.(2014).Nigeria and education: The challenges ahead. Education Legal and Management studies.4, 7-15.

Apeabu, J. A. (2014). Education for all: A look at the school placement program in Nigeria. Zaria Journal of Educational Studies.6, (4), 27-31

Berkowitz, M.W., \& Oser, F.(1985). Moral education: Theory and application. Hillsdale, NJ: Lawrence Erlbaum.

Ballantine, J. H. (2015). School and society: A sociological approach to education. ( $5^{\text {th }}$ Inc.

Chianu, E., (2001). Corporal punishment in primary and secondary schools: Legal Position. Asaba: Endless Books Publishers

Colby, R. (1987). Moral education through drama, 2D, 7(1),72

Durkheim, E. (1968). Moral education. New York: Free Press.

Edmiston, B.(1995).Discovering right actions: forging ethical understandings through dialogic interactions, in P. Taylor\& C. Hoepper (Eds)Selected Readings in Drama and Theatre in Education (Brisbane, NADIE Publications).

Fayose, D. E. (2014). Education for character: Alternative to values clarification and cognitive moral development curriculum. The Journal of Educational Thought, 2(2), 67-76

Hansen, A. (2001), The student as moral agent. Journal of Moral Education, 27(2), 179-190.

Handel, G., Cahill, S. E., \& Elkin, F. (2007).Children and society : The sociology of children and childhood socialization. Los Angeles, CA: Roxbury Publishing Company.

Haralambos, M. \& Heald, R.M. (1980). Sociology term and perspectives. Unwin publisher.

Hurn, C. J. (1993). The limits and possibilities of schooling, An introduction to sociology of education. London. Allyn and Bacon, Inc.

Kotaiah, A.O. (2014). Role of the teacher in development of moral values. International Journal of English Language, Literature and Translation Studies (IJELR). 1(3) 70-73

Macionis,J.J. (1989). Sociology. $2^{\text {nd }}$ Ed. New Jersey: Englewood Cliffy. 
Mannheim, M. \& Stewart, W. A. C. (1980).An introduction to the sociology of education. London: Routledge and Kegan Paul Limited.

Meighan, R. (1977) Sociology of Educating, $2^{\text {nd }}$ Ed. New Jersey: Prentice-Hall,Englewood Cliffs.

Musgrave, P. W. (1968). The Sociology of Education, London; Cox and Wyman Ltd.

Obameata, O. (1995). An appraisal of education and discipline in some selected primary schools in Ilorin Unpublished M.ED. Dissertation, University of Ilorin.

Ottaway, A.K.C. (2010). Durkheim on education. Journal British Journal of Educational Studies 16,(1)5-

16. Available at: https://doi.org/10.1080/00071005.1968.9973204

Power, C. F., Higgins, A..\& Kohlberg, L. (1989). Lawrence Kohlberg's approach to moral education. New York: Columbia University Press.

Rigby, K., (2011). Bullying in schools and what to do about it. London: Jessica Kigsley.

Ryan, K. (1986). The new moral education. Phi Delta Kappan, 68 (4), 228-233. Retrieved from: http: hi-ho.ne.jp/taku77/refer/ryan.htm

Ryan, K., \& Bohlin, K. (1999). Building character in schools. San Francisco: Jossey-Bass.

Sanderse, W. (2012).The meaning of role modelling in moral and character education. Journal of Moral Education,42(1),28-42.doi:10.1080/03057240.2012.690727

The Research Advisors, (2006), Sample size table. Retrieved from: http://research-advisors.com.

Winston, J. (1996). Emotion, reason, and moral engagement in drama, Research in Drama Education,1 (2), 189- 200.

Winston, J. (2010). Drama, narrative and moral Education: exploring traditional tales in the primary years (London, Falmer)

Williams, D. D., Yanchar, S. C., Jensen, L. C. \& Lewis, C. (2003). Character education in a public high school: a multi-year inquiry into Unified Studies. Journal of Moral Education, 32(1), 3-34. 